\title{
IMPLEMENTATION OF LEAN WAREHOUSE TO MINIMIZE WASTES IN FINISHED GOODS WAREHOUSE OF PT. CHAROEN POKPHAND INDONESIA SEMARANG
}

\author{
Nia Budi Puspitasari'; Audy Yumna Ardila² \\ ${ }^{1,2}$ Industrial Engineering Departement, Engineering Faculty, Diponegoro University \\ Jl. Prof. Sudharto, Tembalang, Semarang \\ 1niabudipuspitasari@gmail.com; ${ }^{2}$ audyardila@gmail.com
}

\begin{abstract}
PT. Charoen Pokphand Indonesia Semarang is one of the largest poultry feed companies in Indonesia. To store the finished products that are ready to be distributed, it needs a finished goods warehouse. To minimize the wastes that occur in the process of warehousing the finished goods, the implementation of lean warehouse is required. The core process of finished goods warehouse is the process of putting bag that has been through the process of pallets packing, and then transporting the pallets contained bags of feed at finished goods warehouses and the process of unloading food from the finished goods warehouse to the distribution truck. With the implementation of the lean warehouse, we can know whether the activities are value added or not, to be identified later which type of waste happened. Opinions of stakeholders regarding the waste that must be eliminated first need to be determined by questionnaires. Based on the results of the questionnaires, three top wastes are selected to be identified the cause by using fishbone diagram. They can be repaired by using the implementation of 5S, namely Seiri, Seiton, Seiso, Seiketsu, and Shitsuke. Defect waste can be minimized by selecting pallet, putting sack correctly, forklift line clearance, applying working procedures, and creating cleaning schedule. Next, overprocessing waste is minimized by removing unnecessary items, putting based on the date of manufacture, and manufacture of feed plan. Inventory waste is minimized by removing junks, putting feed based on the expired date, and cleaning the barn.
\end{abstract}

Keywords: lean, waste, value stream mapping, warehouse of finished goods

\section{INTRODUCTION}

Charoen Pokphand Group is a group of animal feed company and the largest processed chicken factory in Indonesia. PT. Charoen Pokphand Indonesia Semarang is a subsidiary of Charoen Pokphand Group, which is engaged in the production of animal feed. There are more than 100 kinds of poultry and pork feeds produced by this company.

In a manufacturing company, the warehouse is an important part. Warehouse gathers on the company's assets, especially in the finished goods warehouse. Therefore, warehouse requires special attention to function properly. Lean is a continuous effort to eliminate wastes and increase the value added of a product to give value to the customers (Gaspersz, 2007). Warehousing systems are less well able to cause waste. In the processes of the finished goods, the warehouse is still widely available of waste or extravagances. Value stream map is an effective way to find waste and showed improvement process (Womack, 2003). Value Stream Mapping wastes can be viewed at a glance regarding what is happening in the warehousing process. According to observations, problems that often lead to waste in warehousing process are the speed of the packing process that cannot balance the process of unloading the warehouse. There is still a structuring palette that does not in sequence 
and must be ordered in advance, warehouse located far from the loading process to the truck, feed expired, and torn bags after it is loaded in the warehouse.

To be more easily identified, the wastes are divided into seven wastes such as overproduction waste, waste of waiting that occurs. The time needed for the process of packing one bag is 8.9 seconds while to load one bag of feed to the barn only takes 7.5 seconds. Transportation waste that occurs when the operators lay the feed in the farther barn (Warehouse 7) takes longer than the near warehouse (Warehouse 2). Overprocessing waste that occurs when the transfer of feed for the most recent feed should be placed in the back makes the forklift had to work twice. An unnecessary movement that occurs when it takes three workers on the packing line, but one of the workers had to take a bag and label it left only two people, and productivity was reduced which could reach eight bags/minute, dropped to 4-6 bags/min. Waste of inventory that occurs when data feed expired from the date of February 23, 2015, shows that there are 320 bags expired. A defect that occurs with the report of torn (repacking) feeds data dated February 24, 2015, there was a total of 70 bags torn by the number of repairs just as many as 46 bags.

After being identified, the most waste by the completion criteria are based on the intensity, easy to remove and incurred losses will be analyzed with the fishbone diagram. Then, improvements will be recommended by using the principles of 5S. 5S is a method of structuring and maintenance intensive work areas from Japan that are used by management in maintaining order, efficiency, and discipline at the work site at the same time improve the company's overall performance. This method is suitable for solving problems in the finished goods warehouse because there are analysis and recommendations regarding conciseness, neatness, cleanliness, steadiness, and craft of a field. Therefore, by applying 5S, it is expected for the existing wastes to be minimized. The goals of this study include analysing the waste that occurs in the system of warehousing finished goods of PT. Charoen Pokphand Indonesia Semarang and proposed value added to the activities in the Finished Goods Warehouse of PT. Charoen Pokphand Indonesia Semarang so that the design improvements can create efficient, smooth and comfortable production process.

\section{METHODS}

Sequence of the research methods of this study can be seen in Figure 1.
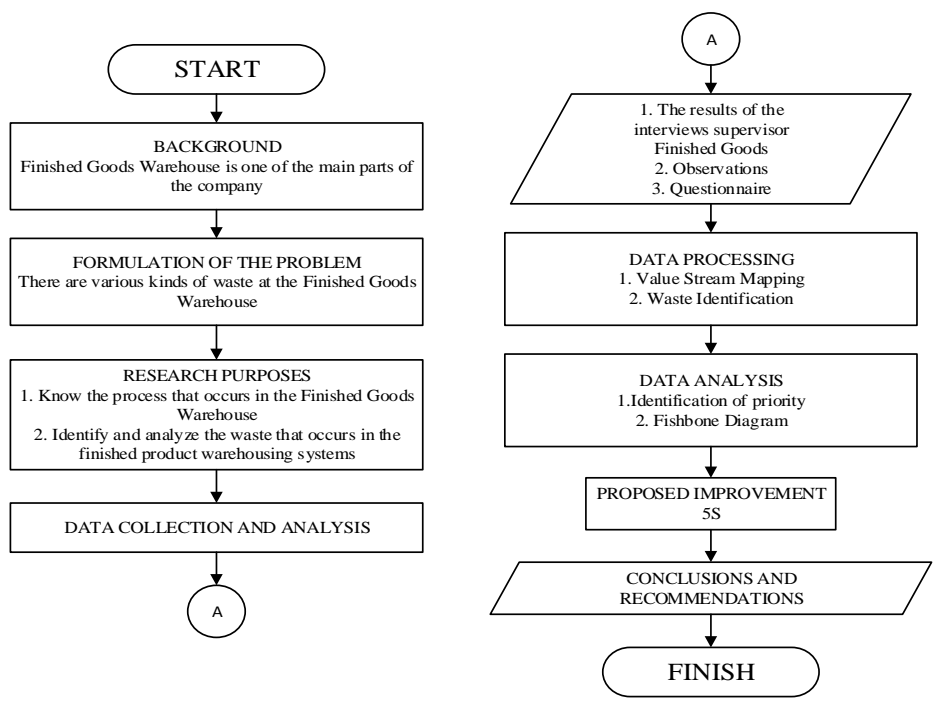

Figure 1 Research Methods 
In the stage of data processing, data are required to conduct research and discuss the issues contained in the finished goods warehouse. The data obtained from interviews, the actual data, observations and questionnaires distributed to employees who play an important role in the finished goods warehouse. Data processing is done by Value Stream Mapping and seven wastes identification that occur in the warehouse finished well. Then do the data analysis by using weighting the wastes obtained from questionnaires for five employees finished goods warehouse, and then determines the three most influential waste.

Problem solved in some source of the problem by using a fishbone diagram. Fishbone diagram is a diagram that is used to identify the cause of the problem. Fishbone diagram is an analytical tool that provides a systematic way of looking at the causes and consequences that arise, or contribute to a result. Because of this function, Fishbone diagrams are also referred to as a causeeffect diagram (Wibisono, 2006). Proposed improvements of the most influential waste that have been determined is with the implementation of $5 \mathrm{~S}$ in the parts warehouse finished goods contained waste. From the data processing and analysis, the conclusion concerns about the issues of what happens in the finished goods warehouse and how to mitigate them. Advice is also provided to reduce the risk of error in the study; to be a correction in subsequent studies.

\section{RESULTS AND DISCUSSIONS}

Stages of data collection and processing can be done by interviews, direct observation, and questionnaires (Fanani, 2011). This stage can be divided into several steps, namely (1) the depiction of value stream mapping, (2) description of wastes, (3) determination omitted waste should preemptively (questionnaire), (4) making fishbone diagram, and (5) proposed improvements (5S)

From the observations, recapitulation load speed which can be seen in Table 1 is obtained.

Table 1 Recapitulation of The Load Speed Process

\begin{tabular}{crc}
\hline Process & Velocity & Satuan \\
\hline Packing - Pallet & 6,67 & Bags/minute \\
& 333,34 & $\mathrm{kgs} /$ minute \\
& 0,33 & tons/minute \\
Pallet - Warehouse & 8 & Bags/minute \\
*company statutes & 400 & $\mathrm{kgs} /$ minute \\
& 0,4 & tons/minute \\
Warehouse - Truck & 17,22 & Bags/minute \\
& 860,98 & $\mathrm{kgs} /$ minute \\
& 0,86 & tons/minute \\
\hline
\end{tabular}

\section{Value Stream Mapping}

Value Stream Mapping of the finished warehouse goods of PT. Charoen Pokphand Indonesia Semarang can be seen in Figure 2. The translation through Value Stream Mapping is useful to know the details of the existing warehousing activities for later to identify the wastes occured. 


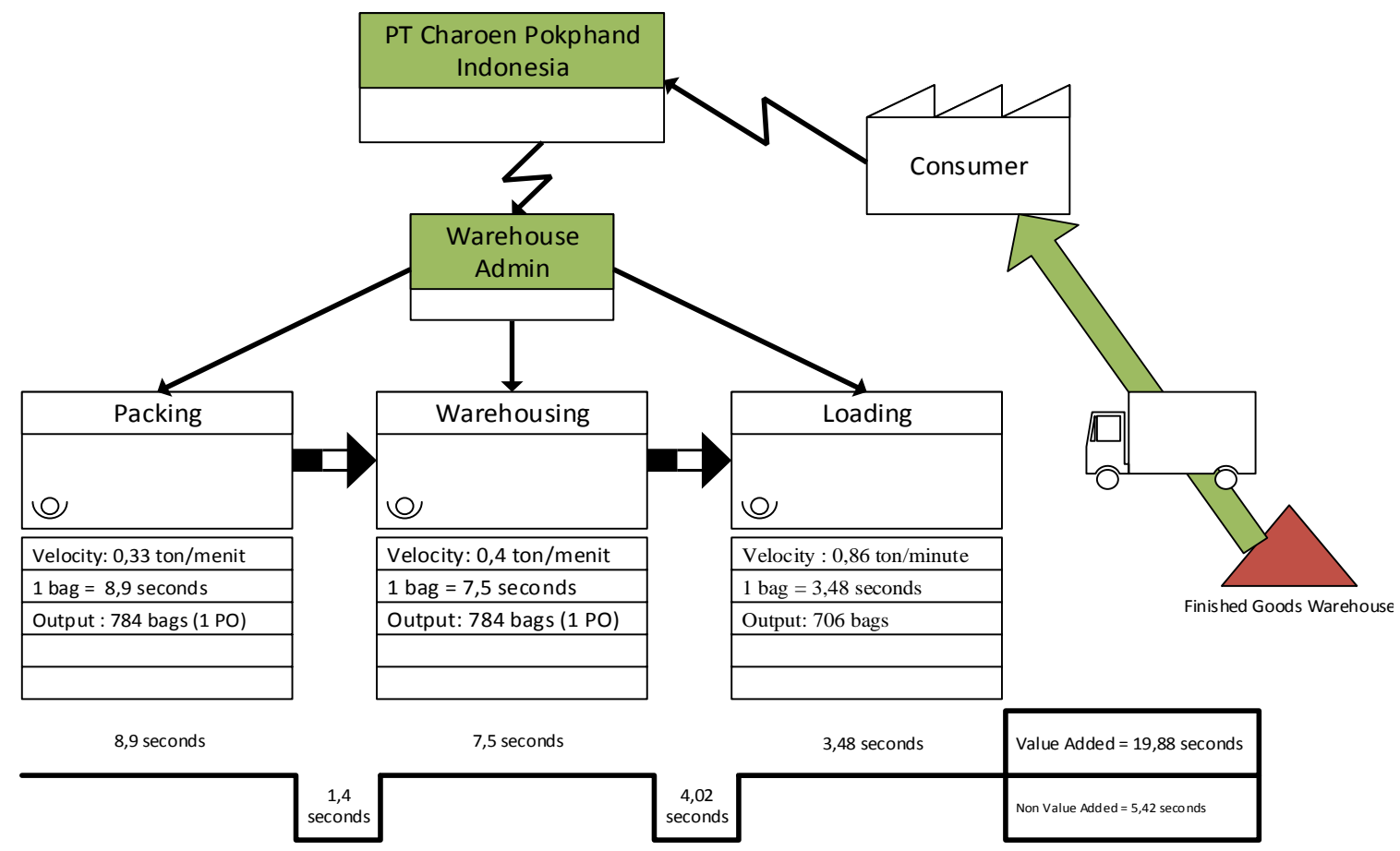

Figure 2 Value Stream Mapping

Table 2 Recapitulation of the Warehousing Activities

\begin{tabular}{|c|c|c|c|c|}
\hline No & Activity & Velocity & Output & Annotation \\
\hline 1 & Packing & 0,33 ton / minute & 784 bags & NVA \\
\hline 2 & $\begin{array}{c}\text { Warehousing } \\
\text { * company statutes }\end{array}$ & 0,4 ton / minute & 784 bags & VA \\
\hline 3 & Loading & 0,86 ton/minute & 706 bag & VA \\
\hline
\end{tabular}

\section{Description of Wastes}

Firstly, overproduction waste does not occur at the Finished Goods Warehouse PT. Charoen Pokphand Indonesia Semarang, this is because the production process is not the responsibility part of Finished Goods. Finished Goods section only has authority on finished goods through the packing process (the last process in the production).

The second waste to be described is waste of waiting. From the Value Stream Mapping, it can be seen that when measured by tonnage, a truckload speed is much faster than the speed of unloading of finished goods to the warehouse and packing. The packing speed of $0.33 \mathrm{tons} / \mathrm{min}$, fit into the finished goods warehouse 0,4 tons $/ \mathrm{min}$, and loaded into trucks 0.86 tons $/ \mathrm{min}$. However, there was no downtime between the warehouse load of finished good to truck loading. Process of truck loading will happen if there is DO (Delivery Order) of the code of feed given, thus there is available stock for the type of feed ordered in the warehouse and then it will be issued by the appropriate FIFO principle (First In First Out). Downtime occurs between the packing process and the unloading process to the finished goods warehouse. From the speed, the packing of T 24 P feed unable to compensate the loading process to the warehouse with a forklift. Productivity of both processes is about $0.07 \mathrm{tons} / \mathrm{min}$ or $70 \mathrm{kgs} / \mathrm{min}$, and when converted, there is one to two bags that are not transported in every minute. 
Third, transportation waste occurs when the forklift must move the finished goods to the far warehouse. From the floor plan of the warehouse below, it can be seen that warehouse 7 is the farthest from the line of packing and the closest warehouse to the packing line is warehouse 2 . Warehouse 7 is within \pm 30 meters from the packing line, while warehouse 2 is only \pm 5 meters from the packing line. The real form of waste in this section is the fuel wasting of forklift. Each day, the storeroom warehouse provides 500L diesel for 15 units of forklifts. Thus, every forklift at least get a ration of about 33L a day.

This is also caused by the placement of unobserved slow-moving and fast-moving warehouses. Supposedly products that are often loaded onto trucks placed in the most strategic packing area and unloading to the truck area. Sketch of finished goods warehouse can be seen in Figure 3.

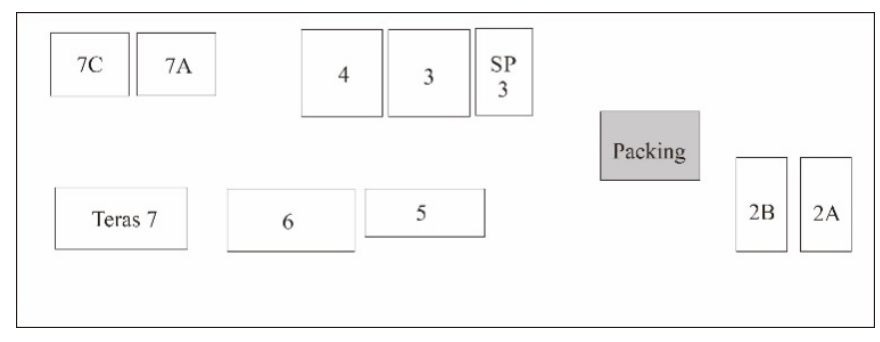

Figure 3 Finished Goods Warehouse Layout

Fourth, overprocessing waste occurs during the process of laying the feed in the finished warehouse goods. The new feed demands the back spot the old so that the feed must be removed first in order by the provisions of FIFO (First In First Out). The transfer is done with the aid of a forklift feed with removal costs of Rp. 2000 per each removal. Thus, when the removal is done every day, then the company will suffer losses. There is a loss of at least 500,000, - a day just to move the feed that should be placed directly on the correct layout.

Fifth, unnecessary movement occurs in the process of packing. Packing process is done by dividing the entire stock into three shifts. There are five packing lines for each type of different PO (Production Order). Each of these lines requires at least three workers. Three workers include one person to take the sack and put it at the end of the bin. Then, one person to put the sack on the sewing machine, insert label and cut the thread and then lower it to the pallet. Finally, one more person is needed to arrange bag on a pallet up to 49 bags. Unnecessary movement occurs when one of the three operators from one section of the packing line had to create a new label or take a new sack thus leaving his job. Therefore, the packing process becomes slower than it should be.

Next, the cause of waste inventory is the dampness of warehouses; mixed, expired, burnt, and crushed, feed, as well as nutrient that is not within specification. Finally, a manufacturing company would not want defective product, it is not at all or zero defect. But in practice, in one production there may be a product that does not meet the specifications that can not be distributed. It also occurs in finished goods warehouse. On the other hand, defect often occurs even though the specifications have been met, such as defects in the sack. Defects in this sack can lead to many things like feed scattered, feed mixed with other materials and feed with decreasing quality. 


\section{Preemptive Determination of Omitted Waste}

In this stage, the weighting of waste often occurs in the finished goods warehouse, where the weighting is based on the seven wastes (Rakhmawati, 2011). Waste identification according to the concept of Lean is by distributing questionnaires (Riandiani, 2011). The weighting of waste derived from the results of a questionnaire given to the five employees who have contributed greatly to the warehouse finished goods PT. Charoen Pokphand Indonesia Semarang, including: (1) Mr. Aninditio as Supervisor, (2) Mrs. Puji as Administrator, (3) Mr. Wahyu as Stock Keeper, (4) Mr. Achmad P. as Controller, (5) Mr. Muchroni as Controller.

Here is the recapitulation of the questionnaire:

Table 3 The Recapitulation Based on Intensity

\begin{tabular}{|c|c|c|c|c|c|c|c|c|c|c|c|}
\hline \multirow{2}{*}{ Num. } & \multirow{2}{*}{ Waste } & \multicolumn{8}{|c|}{ Grade } & \multirow{2}{*}{ Sum } & \multirow{2}{*}{ Weight } \\
\hline & & 1 & 2 & 3 & 4 & 5 & 6 & 7 & 8 & & \\
\hline 1 & Overproduction & & & 1 & & & 4 & & & 15 & 0,074257 \\
\hline 2 & Waiting & & & & 1 & & 3 & 1 & & 29 & 0,143564 \\
\hline 3 & Transportation & & & & & 2 & 2 & & 1 & 30 & 0,148515 \\
\hline 4 & Overprocessing & & & & & 1 & 2 & 1 & 1 & 32 & 0,158416 \\
\hline 5 & Movement & & & & & & 4 & 1 & & 31 & 0,153465 \\
\hline 6 & Inventory & & & & & & 1 & 2 & 1 & 28 & 0,138614 \\
\hline 7 & Defect & & & & & & & 3 & 2 & 37 & 0,183168 \\
\hline \multicolumn{10}{|c|}{ Sum } & 202 & 1 \\
\hline
\end{tabular}

Table 4 The Recapitulation Based on the Easiness to Remove

\begin{tabular}{|c|c|c|c|c|c|c|c|c|c|c|c|}
\hline \multirow{2}{*}{ Num. } & \multirow{2}{*}{ Waste } & \multicolumn{8}{|c|}{ Grade } & \multirow{2}{*}{ Sum } & \multirow{2}{*}{ Weight } \\
\hline & & 1 & 2 & 3 & 4 & 5 & 6 & 7 & 8 & & \\
\hline 1 & Overproduction & & & 1 & 2 & 1 & 1 & & & 22 & 0,134969 \\
\hline 2 & Waiting & & & 2 & 2 & & 1 & & & 20 & 0,122699 \\
\hline 3 & Transportation & & & & 2 & 2 & 1 & & & 24 & 0,147239 \\
\hline 4 & Overprocessing & & & & 1 & 2 & & 1 & 1 & 29 & 0,177914 \\
\hline 5 & Movement & & & 1 & 3 & & & 1 & & 21 & 0,128834 \\
\hline 6 & Inventory & & & & 3 & 1 & 1 & & & 23 & 0,141104 \\
\hline 7 & Defect & & 1 & & 2 & & 1 & & 1 & 24 & 0,147239 \\
\hline & & & $\mathrm{Im}$ & & & & & & & 163 & 1 \\
\hline
\end{tabular}

Table 5 The Recapitulation Based on the Losses Incurred

\begin{tabular}{|c|c|c|c|c|c|c|c|c|c|c|c|}
\hline \multirow{2}{*}{ Num. } & \multirow{2}{*}{ Waste } & \multicolumn{8}{|c|}{ Grade } & \multirow{2}{*}{ Sum } & \multirow{2}{*}{ Weight } \\
\hline & & 1 & 2 & 3 & 4 & 5 & 6 & 7 & 8 & & \\
\hline 1 & Overproduction & & & 1 & 3 & & 1 & & & 21 & 0,123529 \\
\hline 2 & Waiting & & 2 & & 1 & & 1 & 1 & & 21 & 0,123529 \\
\hline 3 & Transportation & & 2 & 1 & & 1 & & 1 & & 19 & 0,111765 \\
\hline 4 & Overprocessing & & 2 & 1 & & & & 1 & 1 & 22 & 0,129412 \\
\hline 5 & Movement & & & 2 & 2 & & & & 1 & 22 & 0,129412 \\
\hline 6 & Inventory & & & & 3 & 1 & 1 & & & 27 & 0,158824 \\
\hline 7 & Defect & & & & 1 & 3 & & & 1 & 38 & 0,223529 \\
\hline & & & & & & & & & & 170 & 1 \\
\hline
\end{tabular}


Table 6 Waste Rank

\begin{tabular}{ccccccc}
\hline \multirow{2}{*}{ Num. } & \multirow{2}{*}{ Waste } & Weight & Sum & Rank & & \\
\cline { 3 - 6 } & & $\mathbf{1}$ & $\mathbf{2}$ & $\mathbf{3}$ & & \\
\hline 1 & Overproduction & 0,074257 & 0,134969 & 0,123529 & 0,332756 & 7 \\
2 & Waiting & 0,143564 & 0,122699 & 0,123529 & 0,389793 & 6 \\
3 & Transportation & 0,148515 & 0,147239 & 0,111765 & 0,407519 & 5 \\
4 & Overprocessing & 0,158416 & 0,177914 & 0,129412 & 0,465742 & 2 \\
5 & Movement & 0,153465 & 0,128834 & 0,129412 & 0,411711 & 4 \\
6 & Inventory & 0,138614 & 0,141104 & 0,158824 & 0,438542 & 3 \\
7 & Defect & 0,183168 & 0,147239 & 0,223529 & 0,553937 & 1 \\
\hline
\end{tabular}

\section{Fishbone Diagram}

Fishbone diagram is a diagram illustrating the causation of a problem. In this case, the four parameters used in assessing the existing problems, namely method, man, material, and machine.

\section{Defect}

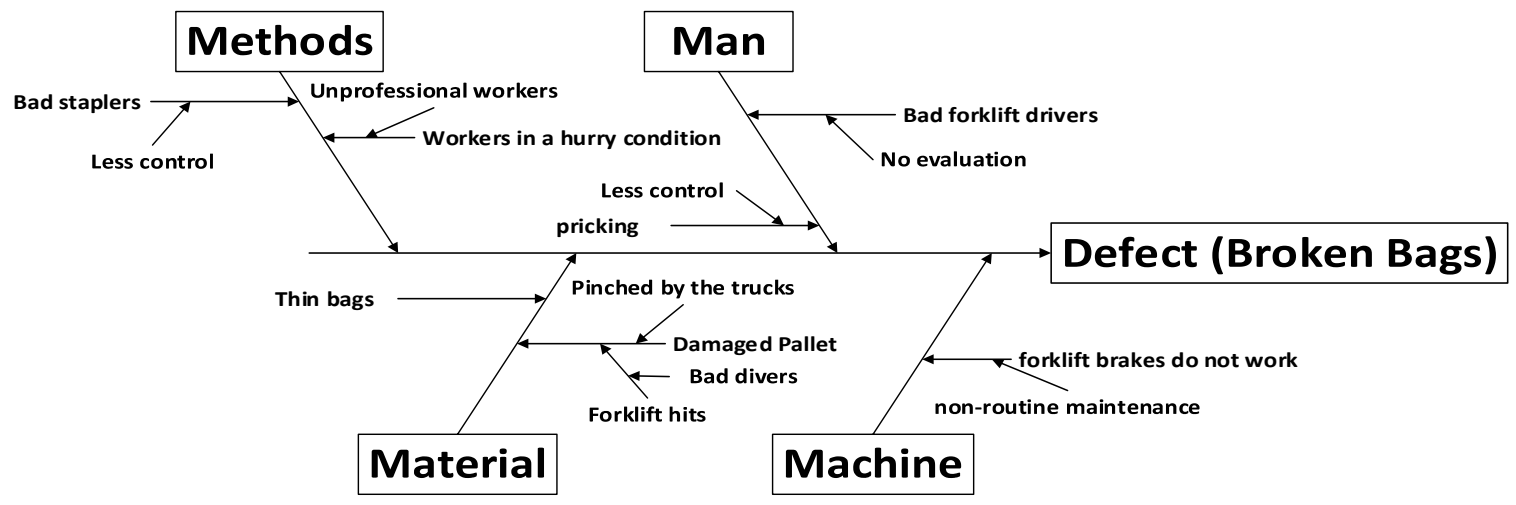

Figure 4 Defect Fishbone Diagram

\section{Overprocessing}

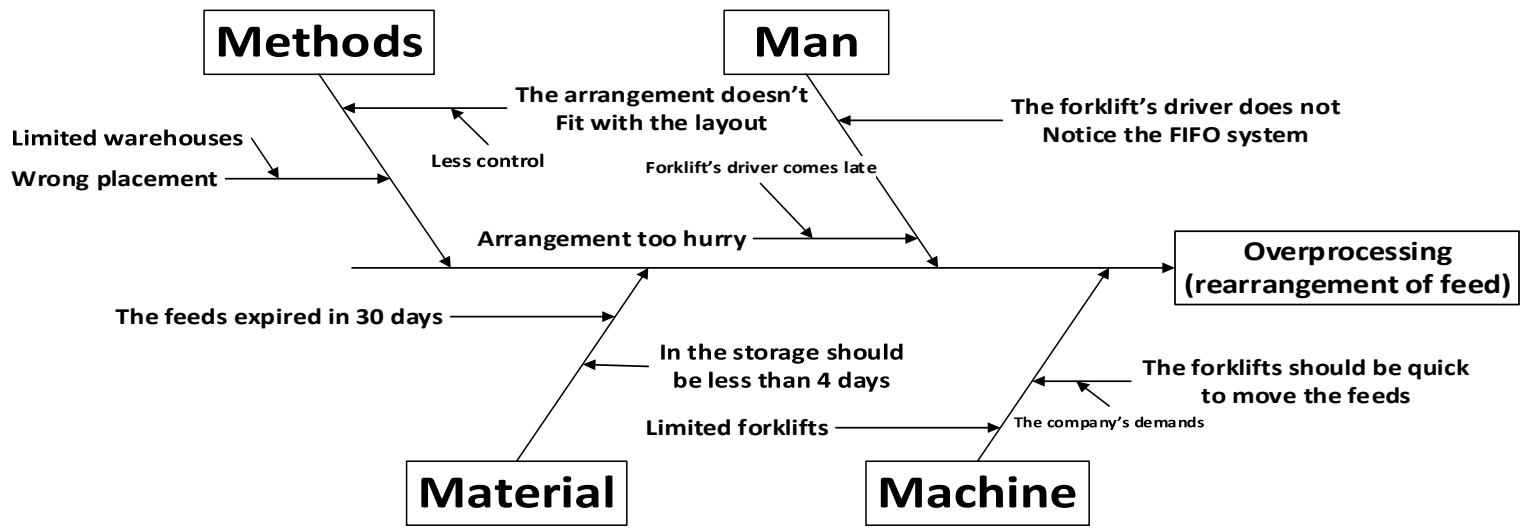

Figure 5 Overprocessing Fishbone Diagram 


\section{Inventory}

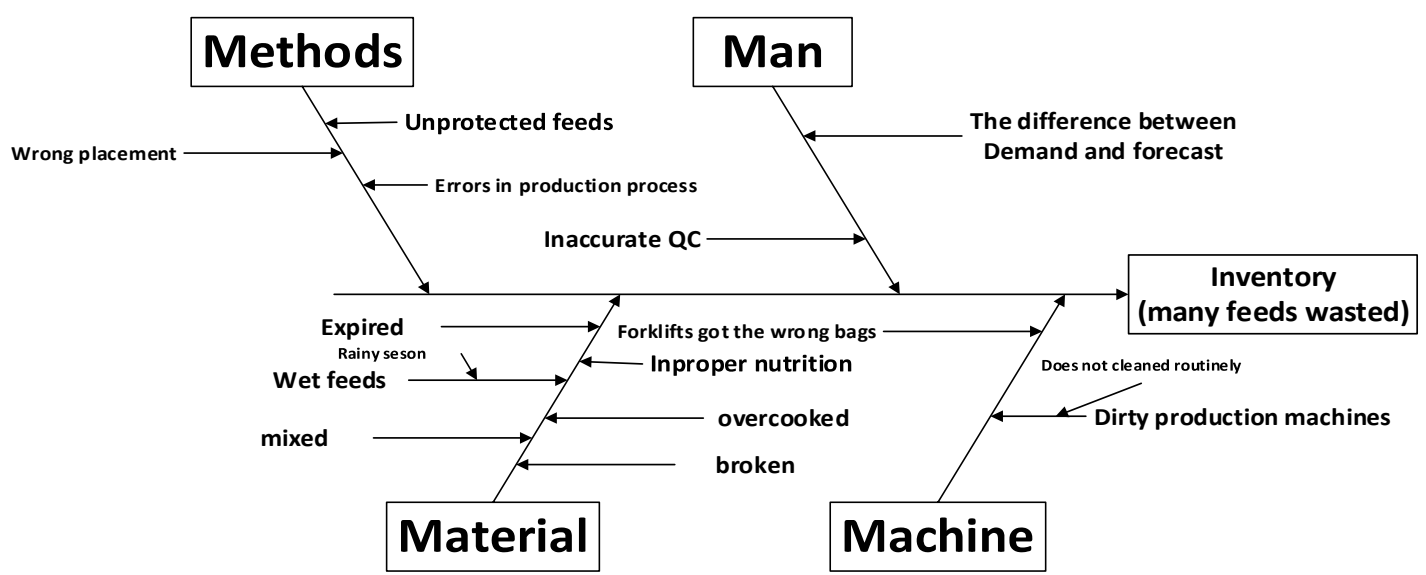

Figure 6 Inventory Fishbone Diagram

\section{Proposed Improvements (5S)}

One of the tools to reduce waste in the concept of lean is to implement the 5S concept. There are several stages in the implementation of $5 \mathrm{~S}$ concept. First, Seiri is a step in selecting the goods used and unused. After the casting is not required, the roots of the problem will be known. Second, Seiton means all the items lay out to suit the place to follow the rules that have been set. Third, Seiso means clean. In this case, the application of the rehearsal is by performing periodic cleaning. The fourth step is Seiketsu. After three aspects are executed, required maintenance is performed continuously so that no back waste that has been successfully minimized. Fifth, Shitsuke associated with doing scheduled activities relating to the above four aspects $5 \mathrm{~S}$, so, in this case, we need a rule and schedule to continue to keep all these aspects in order to run smoothly. Recapitulation 5S implementation can be seen in Table 7.

Table 7 The Implementation of 5S Methods.

\begin{tabular}{|c|c|c|c|c|c|}
\hline \multirow{2}{*}{ Waste } & \multicolumn{5}{|c|}{ 5S Methods } \\
\hline & Seiri & Seiton & Seiso & Seiketsu & Shitsuke \\
\hline Defect & $\begin{array}{l}\text { Selection } \\
\text { palette that } \\
\text { works fine }\end{array}$ & $\begin{array}{c}\text { Sacks be correctly placed } \\
\text { on pallets }\end{array}$ & $\begin{array}{c}\text { Line } \\
\text { clearance } \\
\text { forklift }\end{array}$ & $\begin{array}{c}\text { The application of } \\
\text { working procedures }\end{array}$ & $\begin{array}{c}\text { Making the } \\
\text { hygiene schedule }\end{array}$ \\
\hline Overprocessing & $\begin{array}{c}\text { Throw away } \\
\text { items that are } \\
\text { not needed } \\
\text { around the barn }\end{array}$ & $\begin{array}{l}\text { Laying the feed according } \\
\text { to the date of manufacture, } \\
\text { manufacture of feed plans }\end{array}$ & $\begin{array}{c}\text { cleaning } \\
\text { warehouse }\end{array}$ & $\begin{array}{c}\text { The application of } \\
\text { working procedures }\end{array}$ & $\begin{array}{l}\text { Making a schedule } \\
\text { feed control layout }\end{array}$ \\
\hline Inventory & $\begin{array}{c}\text { Throw away } \\
\text { items that are } \\
\text { not needed } \\
\text { around the barn }\end{array}$ & $\begin{array}{l}\text { Laying the feed according } \\
\text { to the date of manufacture }\end{array}$ & $\begin{array}{c}\text { cleaning } \\
\text { warehouse }\end{array}$ & $\begin{array}{c}\text { The application of } \\
\text { working procedures }\end{array}$ & $\begin{array}{l}\text { Making the } \\
\text { inventory control } \\
\text { schedule }\end{array}$ \\
\hline
\end{tabular}




\section{CONCLUSIONS}

From the research that has been done in the finished goods warehouse PT. Charoen Pokphand Indonesia Semarang, it can be concluded that: first, it can be seen that from the value stream mapping and direct observation, waste that occurs are: (1) Waste of waiting is the waiting process from packing to loading the feed in the warehouse finished goods). (2) Transportation waste that is a long distance in packing with certain warehouses. (3) Waste overprocessing refers to the removal re-feed process in the barn because it is not by the rules of FIFO. (4) Unnecessary movement that is on the packing. there is one line that filled less than three workers for horse's mouth should be doing things like taking a sack or make a label. (5) Waste of inventory i.e. the number of expired food every day. (6) Defect which is the number of bags is torn as a result of storage in a warehouse through the questionnaire can be concluded that the waste should be eliminated first is a defect waste, waste overprocessing, and inventory waste.

Second, based on the fishbone diagram of three wastes that must be eliminated first, given proposed improvements to the finished goods warehouse of PT. Charoen Pokphand Indonesia Semarang is the implementation of the 5S principles, namely: (1) Minimizing Waste Defect by selecting the palette that works well, sacks placed properly on pallets, forklifts line clearance, the application of working procedures, and creating a schedule cleanliness. (2) Minimizing Waste Overprocessing by removing items that are not needed around the barn, Laying of feed according to the date of manufacture, the manufacturer of feed plan, cleaning the warehouse, application procedures, and creating a schedule feed control layout. (3) Minimizing Waste Inventory by removing items that are not needed around the barn, feed the laying of the date of manufacture, cleaning the barn, the application of working procedures, inventory control, and scheduling.

\section{REFERENCES}

Fanani, Z. (2011). Implementasi Lean Manufacturing untuk Peningkatan Produktivitas (Studi Kasus pada PT. Ekamas Fortuna Malang). Seminar Nasional Manajemen Teknologi XIII. Retrieved February 11, 2015 from http://personal.its.ac.id

Gaspersz, V. (2007). Lean Six Sigma for Manufacturing and Service Industries. Jakarta: PT. Gramedia Pustaka Utama.

Rakhmawati. (2011). Identifikasi Waste pada Wholestream Perusahaan Rokok Di PT. X16. Agrointek, 5(1). Retrieved February 11, 2015 from http://pertanian.trunojoyo.ac.id

Riandiani, R. (2011). Analisa Perbaikan Proses Produksi pada Proses Pembuatan Guitar Akustik dengan Pendekatan Lean Six- Sigma Menggunakan Metode FMEA. (Failure Mode and Effects Analysis) Di UKM. Sentana Art, Solo (Undergraduate's thesis, Institut Teknologi Sepuluh Nopember Surabaya, Surabaya, Indonesia). Retrieved February 24, 2015 from http://digilib.its.ac.id

Wibisono, D. (2006). Manajemen Kinerja. Jakarta: Penerbit Erlangga.

Womack, J. P. (2003). Lean Thinking. New York: Free Press. 